\title{
Editorial RES 1/2017
}

The title of this RES issue does not present a neutral topic. It already contains a thesis which one can accept or contradict. The thesis is that in ecumenical relations, and thus with regards to the question of church communion or church division in its essence, it is primarily about cultural differences, and only secondarily about dogmatic differences. If one discussed questions pertaining to dogma, and if one limited oneself to this field - if the above thesis is correct - this would make little or no meaning because the question of mutual recognition would be settled on a different and deeper level. Some of the old lines between the churches were occasionally described in this light: the separation of the pre-Chalcedonian churches was operated along the borders of the Roman Empire of that time; The division between East and West (at the symbolic date 1054) is the division between the Latin and the Greek tradition; The Reformation drew a considerable part of its driving force from the distinct mentality of Northern and Central Europe, and thus also from political arrangements.

The cultural differences that are addressed here can be considered by taking into consideration a variety of factors: language, history, mentality, social structure, folk traditions, economic conditions, and many more.
Der Titel dieser Nummer von RES ist keine neutrale Themenanzeige. Er enthält bereits eine These, der man zustimmen oder widersprechen kann. Die These lautet, dass es in den ökumenischen Beziehungen und damit in der Frage nach Kirchengemeinschaft oder Kirchenspaltung im Kern, und damit in erster Linie, um kulturelle Differenzen geht, und nur damit zusammenhängend und sekundär um dogmatische Unterschiede. Wenn man über Streitfragen auf dem Gebiet der Dogmatik diskutiert und sich auf diese Ebene beschränkt, hätte das - wenn die genannte These stimmt - wenig Sinn, weil die Frage nach gegenseitiger Anerkennung auf einer anderen, tieferen Ebene entschieden wird. Einige der alten Bruchlinien zwischen den Kirchen wurden ja gelegentlich in diesem Licht beschrieben: die Trennung der vorchalcedonensischen Kirchen erfolgte entlang der damaligen Reichsgrenzen; die Spaltung zwischen Ost und West (mit dem Symboldatum 1054) ist eine zwischen lateinischer und griechischer Tradition; die Reformation schöpfte einen bedeutenden Teil ihrer Triebkraft aus der anders gearteten Mentalität in Nordund Mitteleuropa und damit auch aus politischen Konstellationen.

Bei den kulturellen Differenzen, die hier angesprochen sind, kann an 
Of course, the church is shaped by all these. But how sure can one be that this actually weighs heavier than the known dogmatic differences, which were at the forefront of the ecumenical dialogue most of the times? How could it happen that these dogmatic differences were then so strongly consolidated and pushed to the fore that they became a real obstacle in the ecumenical approach?

If the thesis which is implicit in the title of RES were correct and if it were seriously considered, it would have far-reaching implications for the way in which the ecumenical dialogue should be conducted. The goal then would no longer be the unmediated understanding of dogmatic or ethical questions, but a rerouting of the theological points of contention to their underlying cultural differences and the question of the meaning of this cultural (historical, linguistic) diversity for the community of the churches. It could be seen as an expression of the catholicity of the Church - a catholicity that does not exclude diversity, but cherishes it because it is the indication that the Gospel has reached all peoples. This comprehensive breadth and richness could be then interpreted as a testimony of the truth of the triune God. From this perspective, how can one answer the questions of where should one set limits to this diversity and of the criteria that determine it?

Each of the contributions to RES is a unique reflection in this wide fi- eine Vielzahl von Faktoren gedacht werden: Sprache, Geschichte, Mentalität, Sozialstruktur, Volkstraditionen, wirtschaftliche Verhältnisse, und vieles mehr. Selbstverständlich ist die Kirche von all dem mit geprägt. Aber wie weit kann man sagen, dass dies tatsächlich schwerer wiegt als die bekannten dogmatischen Differenzen, die im ökumenischen Dialog zumeist auf dem Vordergrund standen? Wie konnte es dazu kommen, dass sich diese dogmatischen Differenzen dann doch so sehr verfestigt und auf den Vordergrund geschoben haben, dass sie zu einem tatsächlichen Hindernis in der ökumenischen Annäherung wurden?

Wenn die These, die im Titel von RES steckt, Wahrheit enthält und ernst genommen würde, hätte das weitreichende Folgen für die Art, wie der ökumenische Dialog geführt werden müsste. Das Ziel wäre dann nicht mehr eine direkte Verständigung über dogmatische oder ethische Fragen, sondern es ginge um eine Rückführung der theologischen Streitpunkte auf ihre zugrundeliegenden kulturellen Differenzen und um die Frage, was diese kulturelle (geschichtliche, sprachliche) Vielfalt für die Gemeinschaft der Kirchen bedeutet. Man könnte sie als Ausdruck der Katholizität der Kirche sehen - einer Katholizität, die Vielfalt gerade nicht ausschließt, sondern wertschätzt, weil sie der Ausdruck dafür ist, dass das Evangelium alle Völker erreicht hat. Diese umfassende Weite und 
eld of topics. Yauheniya Danilovich offers an overview and presents the issues raised by relating denominational identity to a specific language. Eveline Cioflec approaches the question of what is meant by the concept of cultural differences from the philosophical point of view, and describes the addressing of these differences with the key phrase meeting the foreigner. Ciprian Iulian Toroczkai takes up the concept of Christian Hellenism, which Georges V Florovsky had significantly influenced, and wonders how one can combine Florovsky's thesis of a philosophia perennis with the ecumenical commitment of this Orthodox theologian. Alina Pătru expands the view on Judaism: in different contexts of the diaspora, different forms of piety have developed as well, despite the fundamental unity of the people and its religion.

Two essays approach the topic from yet another side. Hans Klein sees a link between cultural differences and geographic and climatic conditions which have shaped different forms of life and mentalities. Dorin Oancea asks about the influences that define the life of a person and thus also make up his identity; these ties can be helpful or hindering in the ecumenical dialogue.

In the section 'Other essays', Cristian Sonea presents a study on the concept of missio Dei, which plays an important role in mission theology, irrespective of confession. The
Fülle könnte dann geradezu als ein Zeugnis für die Wahrheit des dreieinigen Gottes verstanden werden. Wie kann in dieser Perspektive dann aber die Frage beantwortet werden, wo die Grenzen der Vielfalt liegen und nach welchen Kriterien diese bestimmt wird?

Die Beiträge in RES sind einzelne Gedankenanstöße in diesem weiten Themenfeld. Yauheniya Danilovich bietet eine Übersicht und Problemanzeige zur Frage der Bindung von konfessioneller Identität an eine bestimmte Sprache. Eveline Cioflec nähert sich aus philosophischer Perspektive der Frage, was mit dem Begriff der kulturellen Differenzen gemeint ist, und beschreibt die Auseinandersetzung mit diesen Differenzen unter dem Stichwort der Begegnung mit dem Fremden. Ciprian Iulian Toroczkai greift den Begriif des christlichen Hellenismus auf, den Georges V. Florovsky wesentlich mit geprägt hatte, und fragt sich, wie dessen These von einer philosophia perennis mit dem ökumenischen Engagement dieses orthodoxen Theologen zusammen gesehen werden kann. Alina Pătru weitet den Blick auf das Judentum hin aus: auch dort haben sich, trotz der grundsätzlichen Einheit von Volk und Religion, in den unterschiedlichen Kontexten der Diaspora unterschiedliche Formen der Frömmigkeit herausgebildet.

Zwei Essays nähern sich dem Thema nochmals von einer je anderen Seite. Hans Klein sieht einen Zusam- 
challenges of the mission were the ones that shaped the beginning of the ecumenical movement a hundred years ago. The consideration that one speaks about one Gospel, the message of God's salvific action on all His creation, brought and brings Christians together and above all differences. Missio Dei: even ecumenism is not the work of men, but the work of God. This could and should make everyone who takes part in it open and receptive. menhang zwischen den kulturellen Differenzen und den geografischen und klimatischen Verhältnissen, die unterschiedliche Lebensformen und Mentalitäten geprägt hatten. Dorin Oancea fragt nach den Bindungen, die das Leben eines Menschen bestimmen und damit auch dessen Identität ausmachen; diese Bindungen können im ökumenischen Dialog hilfreich oder hinderlich sein.

Unter der Rubrik 'Andere Aufsätze' bringt Cristian Sonea eine Studie zum Konzept der missio Dei, die in der Missionstheologie eine wichtige Rolle spielt, und zwar konfessionsübergreifend. Die Herausforderungen der Mission waren es ja, die den Beginn der ökumenischen Bewegung vor hundert Jahren wesentlich mit geprägt hatten. Die Besinnung darauf, dass es um das eine Evangelium geht, um die Botschaft vom heilbringenden Handeln Gottes mit seiner ganzen Schöpfung, brachte und bringt Christen zueinander, über alle Differenzen hinweg. Missio Dei: auch die Ökumene ist nicht Werk der Menschen, sondern Werk Gottes. Dies könnte und sollte alle Beteiligten offen und lernbereit machen. 